\title{
Identification of Promising Antifungal Drugs against Scedosporium and Lomentospora Species after Screening of Pathogen Box Library
}

\author{
Rodrigo Rollin-Pinheiro 1(D), Luana Pereira Borba-Santos ${ }^{2}$ (D), Mariana Ingrid Dutra da Silva Xisto ${ }^{1}(\mathbb{D}$, \\ Yuri de Castro-Almeida ${ }^{1}$, Victor Pereira Rochetti ${ }^{1}$, Sonia Rozental ${ }^{2}$ and Eliana Barreto-Bergter $1, * \mathbb{C}$ \\ 1 Departamento de Microbiologia Geral, Instituto de Microbiologia Paulo de Góes, Universidade Federal do \\ Rio de Janeiro, Rio de Janeiro 21941-902, Brazil; rodrigorollin@gmail.com (R.R.-P.); \\ marylanax@gmail.com (M.I.D.d.S.X.); yuricastro20155@gmail.com (Y.d.C.-A.); \\ victorrochetti@gmail.com (V.P.R.) \\ 2 Programa de Biologia Celular e Parasitologia, Instituto de Biofísica Carlos Chagas Filho, \\ Universidade Federal do Rio de Janeiro, Rio de Janeiro 21941-902, Brazil; luanaborba@biof.ufrj.br (L.P.B.-S.); \\ rozental@biof.ufrj.br (S.R.) \\ * Correspondence: eliana.bergter@micro.ufrj.br; Tel.: +55-(21)-3938-6741
}

Citation: Rollin-Pinheiro, R.; Borba-Santos, L.P.; da Silva Xisto, M.I.D.; de Castro-Almeida, Y.; Rochetti, V.P.; Rozental, S.; Barreto-Bergter, E. Identification of Promising Antifungal Drugs against Scedosporium and Lomentospora Species after Screening of Pathogen Box Library. J. Fungi 2021, 7, 803. https://doi.org/10.3390/jof7100803

Academic Editor: Ronen Ben-Ami

Received: 28 August 2021

Accepted: 23 September 2021

Published: 25 September 2021

Publisher's Note: MDPI stays neutra with regard to jurisdictional claims in published maps and institutional affiliations.

Copyright: (c) 2021 by the authors. Licensee MDPI, Basel, Switzerland. This article is an open access article distributed under the terms and conditions of the Creative Commons Attribution (CC BY) license (https:// creativecommons.org/licenses/by/ $4.0 /)$.
Abstract: Fungal infections have been increasing during the last decades. Scedosporium and Lomentospora species are filamentous fungi most associated to those infections, especially in immunocompromised patients. Considering the limited options of treatment and the emergence of resistant isolates, an increasing concern motivates the development of new therapeutic alternatives. In this context, the present study screened the Pathogen Box library to identify compounds with antifungal activity against Scedosporium and Lomentospora. Using antifungal susceptibility tests, biofilm analysis, scanning electron microscopy (SEM), and synergism assay, auranofin and iodoquinol were found to present promising repurposing applications. Both compounds were active against different Scedosporium and Lomentospora, including planktonic cells and biofilm. SEM revealed morphological alterations and synergism analysis showed that both drugs present positive interactions with voriconazole, fluconazole, and caspofungin. These data suggest that auranofin and iodoquinol are promising compounds to be studied as repurposing approaches against scedosporiosis and lomentosporiosis.

Keywords: Pathogen Box; Scedosporium; antifungal drugs; drug repurposing; biofilm; fungal growth

\section{Introduction}

Fungal infections have been emerging during the last decades as a consequence of increasing numbers of individuals suffering from health problems, such as diabetes, chemotherapy for cancer treatment, HIV/AIDS, and other immunosuppressive conditions [1,2]. In this context, Scedosporium and Lomentospora species constitute a relevant group of filamentous fungi that cause a wide range of clinical manifestations, being considered emergent pathogens since its incidence increased in the last decades in Europe, America, Asia, and Oceania [3,4]. Scedosporiosis and lomentosporiosis are usually associated with organ transplant recipients, near-drowning people, and HIV / AIDS patients, in which invasive infections can be observed [5]. In addition, they are the second most frequent cause of pulmonary fungal infections in cystic fibrosis patients [6]. In immunocompetent patients, Scedosporium and Lomentospora species cause superficial and cutaneous infections, such as mycetoma, which can lead to the amputation of the affected member in the absence of suitable treatment [3].

The treatment of fungal infections, including scedosporiosis and lomentosporiosis, is limited due to the few antifungal drugs available in clinical settings. Currently, only three classes of antifungals are commonly used to treat mycoses, such as polyenes that directly 
target ergosterol on the fungal membrane, azoles that inhibit the synthesis of ergosterol, and echinocandins that block the synthesis of $\beta$-glucan on fungal cell wall [7,8]. In addition, all these drugs display significant levels of toxicity and side effects, which limits their use, especially in patients presenting underlying disease. Several studies have shown that Scedosporium and Lomentospora species are known as resistant fungi due to their limited susceptibility to all current antifungal agents presented in clinical studies, which makes their treatment a challenge in healthcare settings [3,9-13]. According to the European Confederation of Medical Mycology (ECMM), voriconazole is suggested as the first choice of treatment for Scedosporium and Lomentospora infections, whereas other azoles, such as fluconazole and itraconazole, present low in vitro activity and higher levels of resistance in these species [14]. In vitro resistance to amphotericin B has been repeatedly reported, thus its use is discouraged for scedosporiosis and lomentosporiosis [15]. Reduced susceptibility to echinocandins, such as caspofungin and anidulafungin, has also been demonstrated and their use is only recommended by ECMM as a salvage treatment $[9,14,16]$.

Pathogenic fungi present different mechanism of antifungal resistance. One of the most known is the drug efflux capability, which has already been described in many fungi, such as Candida species and Aspergillus fumigatus, and is one of the most common causes of the resistance to azoles [17-21]. Point mutations in the gene ERG11 that encodes lanosterol $14 \alpha$-demethylase, the target of azoles, are also related to the resistance to this class of antifungals and have already been reported for Candida species, Cryptococcus neoformans and Aspergillus fumigatus [22-25]. Echinocandin resistance is most frequently associated to point mutations in FKS genes, which encodes the $\beta$-glucan synthase [26-28]. Other mechanisms of resistance are known, such as the alterations in metabolic pathways and the regulation of target expression, but the fungal biofilm is one of the most concerning causes of antifungal resistance [28,29]. Its ability to cause antifungal resistance is likely due to multiple factors, such as the presence of an extracellular matrix, the increased expression of efflux pumps, and the modification of plasma membrane composition [30,31]. Biofilms have already been described for many pathogenic fungi, such as Candida and Aspergillus species, C. neoformans, Pichia fabianii, and Trichosporon asahii [30,32-35]. In Scedosporium species, biofilm formation has already been characterized and these structures have been shown to be more resistant to different antifungal drugs [36]. Taking these data into consideration, the development of alternatives to treat these emergent fungal infections is an urgent need.

Screening of compound libraries is a useful approach to identify potential new antifungal drugs, since it optimizes the tests of a large number of candidates in a short period of time. In this context, the Medicines for Malaria Venture (MMV) organization provided libraries that represent a powerful source of compounds. The Pathogen Box library containing 400 compounds with promising activity against neglected pathogens [37] has already been screened against some relevant pathogenic fungi, such as Cryptococcus, Candida, and Sporothrix species, as well as chromoblastomycosis agents. All these studies identified interesting, potent drugs with antifungal properties [38-42].

Considering the relevance of Scedosporium and Lomentospora species as important emerging filamentous fungal pathogens, as well as the potential of a library of compounds to search for new compounds, the present study aimed to screen a total of 400 compounds from the Pathogen Box, to identify promising candidates with anti-Scedosporium and antiLomentospora activity.

\section{Materials and Methods}

\subsection{Strains and Growth Conditions}

Scedosporium aurantiacum CBS 136046, Scedosporium boydii CBS 120157, Scedosporium apiospermum CBS 117407, and Scedosporium dehoogii CBS 117406 were kindly provided by Sybren De Hoog, from the Westerdijk Fungal Biodiversity Institute, Utrecht, the Netherlands. Lomentospora prolificans FMR 3569 was kindly provided by Dr J. Guarro, Unitat de Microbiologia, Facultat de Medicina e Institut d’Estudis Avançats, Réus, Spain. All fungi 
were maintained in modified Sabouraud medium ( $0.5 \%$ yeast extract, $1 \%$ peptone, and $2 \%$ glucose monohydrate). To obtain conidia, cells were grown on plates containing modified Sabouraud agar medium for seven days at room temperature. After that, the surface of the medium was washed with sterile phosphate-buffered saline (PBS, pH 7.2), and the conidia were removed with the aid of a sterile spatula. The cell suspension was filtered and later centrifuged to be used in the experiments.

\subsection{Compounds}

The Medicines for Malaria Venture organization provided the Pathogen Box library, which is composed of 400 compounds at $10 \mathrm{~mm}$ in dimethyl sulfoxide (DMSO). A stock solution of each compound was kept at $1 \mathrm{~mm}$ in DMSO and stored at $-20^{\circ} \mathrm{C}$. Additional experiments were conducted using auranofin and iodoquinol powder (Sigma Chemical Co., St. Louis, MO, USA) dissolved in DMSO and stored at $-20^{\circ} \mathrm{C}$, as well as voriconazole, fluconazole, and caspofungin (Sigma Chemical Co., St. Louis, MO, USA).

\subsection{Screening of the Pathogen Box Library}

The reference isolate S. aurantiacum CBS 136046 was used to screen the Pathogen Box library due to its relevance as a virulent and resistant species from the Scedosporium and Lomentospora groups.

Screening was performed in 96-well microtiter plates containing a final concentration of $5 \mu \mathrm{m}$ of each compound diluted in RPMI 1640 medium (Sigma Chemical Co., St. Louis, $\mathrm{MO}, \mathrm{USA}$ ) supplemented with $2 \%$ glucose and buffered with 3-(N-morpholino) propanesulphonic acid (MOPS) $(0.165 \mathrm{~mol} / \mathrm{L}, \mathrm{pH} 7.2$, from here on referred to as 'supplemented RPMI'). Voriconazole at $5 \mu \mathrm{m}$ and RPMI supplemented with DMSO $1 \%$ were used as controls. Conidia $\left(2 \times 10^{5} / \mathrm{mL}\right)$ were added and incubated for $72 \mathrm{~h}$ at $37^{\circ} \mathrm{C}$ in a $5 \% \mathrm{CO}_{2}$ atmosphere. Fungal growth was analyzed by visual inspection and quantified by optical density readings using a spectrophotometer (Bio-Rad, Hercules, CA, USA) at $600 \mathrm{~nm}$. An inhibition of at least $80 \%$ was defined as a cut-off to select the promising drugs with antifungal activity against Scedosporium and Lomentospora species.

\subsection{Antifungal Susceptibility Testing}

The susceptibility of Scedosporium and Lomentospora species to auranofin and iodoquinol was determined by the broth microdilution method, according to EUCAST protocols, with modifications [43]. Voriconazole was also included in experiments as a reference antifungal because it is the drug of choice for the treatment of scedosporiosis. Briefly, compounds were serially diluted (10-0.078 $\mu \mathrm{m})$ in supplemented RPMI 1640 medium (Sigma Chemical Co., St. Louis, MO, USA) supplemented with $2 \%$ glucose and buffered with 3 -(N-morpholino) propanesulphonic acid (MOPS) $(0.165 \mathrm{~mol} / \mathrm{L}, \mathrm{pH} 7.2)$ in 96 -well microplates. A standardized suspension of conidia $\left(2 \times 10^{5} / \mathrm{mL}\right)$ was added in microplates and incubated for $72 \mathrm{~h}$ at $37^{\circ} \mathrm{C}$, in a $5 \% \mathrm{CO}_{2}$ atmosphere. Fungal growth was analyzed by spectrophotometry readings (Bio-Rad, Hercules, CA, USA) at $600 \mathrm{~nm}$ and cell viability was assessed using the XTT-reduction assay [44]. The minimum inhibitory concentration (MIC) of each compound was defined as the lowest concentration that inhibits $80 \%$ of fungal growth.

\subsection{Biofilm Formation and the Preformed Biofilm Assay}

Biofilm formation was analyzed according to [36]. Briefly, $200 \mu \mathrm{L}$ from a standardized suspension of Scedosporium and Lomentospora conidia $\left(1 \times 10^{7} / \mathrm{mL}\right)$ was added to each well of a polystyrene microplate and incubated for $1.5 \mathrm{~h}$ at $37^{\circ} \mathrm{C}$ for the adhesion step. After that, the supernatant containing non-adherent cells was removed and RPMI 1640 medium supplemented with MOPS, $2 \%$ glucose, and $20 \%$ fetal bovine serum (FBS, Gibco, Waltham, MA, USA) was added in the absence (positive control) or presence of selected compounds $(8-0.25 \times \mathrm{MIC})$. Adherent cells were then incubated for $24 \mathrm{~h}$ at $37^{\circ} \mathrm{C}$. For the preformed biofilm assay, cells were cultured to form biofilm as described above in the absence of the compounds. After $24 \mathrm{~h}$ of biofilm formation, the supernatant was 
removed, and supplemented RPMI was added in the absence (positive control) or presence of the selected compounds (8-0.25 $\times$ MIC). An additional incubation of $24 \mathrm{~h}$ at $37^{\circ} \mathrm{C}$ was performed to evaluate the anti-biofilm activity. Both biofilm formation and preformed biofilms were evaluated using three parameters as previously described [44-46]. Crystal violet, safranin, and XTT assays were used to analyze the overall biomass, extracellular matrix, and metabolic activity, respectively.

\subsection{Scanning Electron Microscopy}

S. aurantiacum cells were grown in supplemented RPMI in the absence or the presence of $2.5 \mu \mathrm{m}$ auranofin $(0.5 \times \mathrm{MIC})$ or $1.2 \mu \mathrm{m}$ iodoquinol $(0.25 \times \mathrm{MIC})$, with orbital agitation $(150 \mathrm{rpm})$ at $37^{\circ} \mathrm{C}$ for $48 \mathrm{~h}$. Fragments of the fungal layer were collected, washed in sterile PBS, and processed according to the following steps:

i. fixation in $2.5 \%$ glutaraldehyde and $4 \%$ formaldehyde, in $0.1 \mathrm{M}$ cacodylate buffer, for $30 \mathrm{~min}$ at room temperature;

ii. wash in $0.1 \mathrm{M}$ cacodylate buffer;

iii. post-fixation in $1 \%$ osmium tetroxide in $0.1 \mathrm{M}$ cacodylate buffer containing $1.25 \%$ potassium ferrocyanide for $30 \mathrm{~min}$;

iv. Wash in $0.1 \mathrm{M}$ cacodylate buffer again;

v. dehydration in a graded ethanol series (30-100\%);

vi. critical point drying in CO2 (EM CPD300, Leica, German);

vii. adhesion to aluminum stubs with carbon tape; and

viii. coating with gold.

Images were obtained with FEI Quanta 250 scanning electron microscope (FEI Company, Hillsboro, OR, USA) and processed using Photoshop software (Adobe, San José, CA, USA).

Measurement of hyphae thickness was performed using the software ImageJ from National Institutes of Health (NIH).

\subsection{Antifungal Drug Synergy Assay}

Synergistic interactions were evaluated by the checkerboard method according to EUCAST guidelines [47]. S. aurantiacum conidia $\left(1 \times 10^{5} / \mathrm{mL}\right)$ were grown in 96-well plates containing supplemented RPMI in the presence of selected compounds $(0.156-10 \mu \mathrm{m})$ combined with fluconazole $(5-320 \mu \mathrm{m})$, voriconazole $(0.47-30 \mu \mathrm{m})$, or caspofungin $(0.625-40 \mu \mathrm{m})$. After incubation for $72 \mathrm{~h}$ at $37^{\circ} \mathrm{C}$, MIC was evaluated at $600 \mathrm{~nm}$ and cell viability was assessed by the XTT-reduction assay at $490 \mathrm{~nm}$ using a spectrophotometer (Bio-Rad, Hercules, CA, USA). An inhibition of at least $80 \%$ was defined as a cut-off for minimum inhibitory concentration (MIC). Minimum effective concentration (MEC) was used to assess caspofungin activity and its interaction with auranofin and iodoquinol, since MEC values are considered more suitable for echinocandins analysis [48]. Interactions were determined by two different methods, the fractional inhibitory concentration index (FICI) and the Bliss independence model.

Fractional inhibitory concentration index was calculated using the following formula: (MIC combined/MIC drug A alone) + (MIC combined/MIC drug B alone). The results were classified as: synergistic effect, FICI of $\leq 0.5$; no effect, FICI of $>0.5-4.0$; antagonistic effect, FICI of $>4.0$ [49].

Bliss independence model was performed according to Meletiadis and colleagues and Zhao and colleagues $[50,51]$. The following formula was used to assess the drug interaction: $E_{\exp }=E_{\mathrm{a}}+E_{\mathrm{b}}-E_{\mathrm{a}} \times E_{\mathrm{b}}$, in which $E_{\exp }$ is the expected efficacy of drug combination, $E_{\mathrm{a}}$ is the efficacy of drug A (auranofin or iodoquinol), and $E_{\mathrm{b}}$ is the efficacy of drug B (fluconazole, voriconazole or caspofungin). The results were classified as: synergistic effect, $E_{\mathrm{obs}}>E_{\exp }$; indifference, $E_{\mathrm{obs}}=E_{\mathrm{exp}}$; antagonistic effect, $E_{\mathrm{obs}}<E_{\mathrm{exp}}$. 


\subsection{Statistical Analyses}

All experiments were performed in triplicate, in three independent experimental sets. Statistical analyses were performed using GraphPad Prism v5.00 for Windows (GraphPad Software, San Diego, CA, USA). The nonparametric Kruskal-Wallis one-way analysis of variance was used to compare the differences among the groups, and individual comparisons of the groups were performed using a Bonferroni post-test. The $90 \%$ or $95 \%$ confidence interval was determined in all experiments.

\section{Results}

\subsection{Screening of Pathogen Box Library}

A total of 400 compounds from the Pathogen Box library were tested against $S$. aurantiacum as reference strain due to its relevance as a highly virulent and resistant species of Scedosporium group [4,52]. The screening revealed six compounds with antifungal activity at $5 \mu \mathrm{m}$, which induced at least $80 \%$ of $S$. aurantiacum inhibition (Figure 1). Voriconazole was used as a control, inducing inhibition of $89.08 \%$.

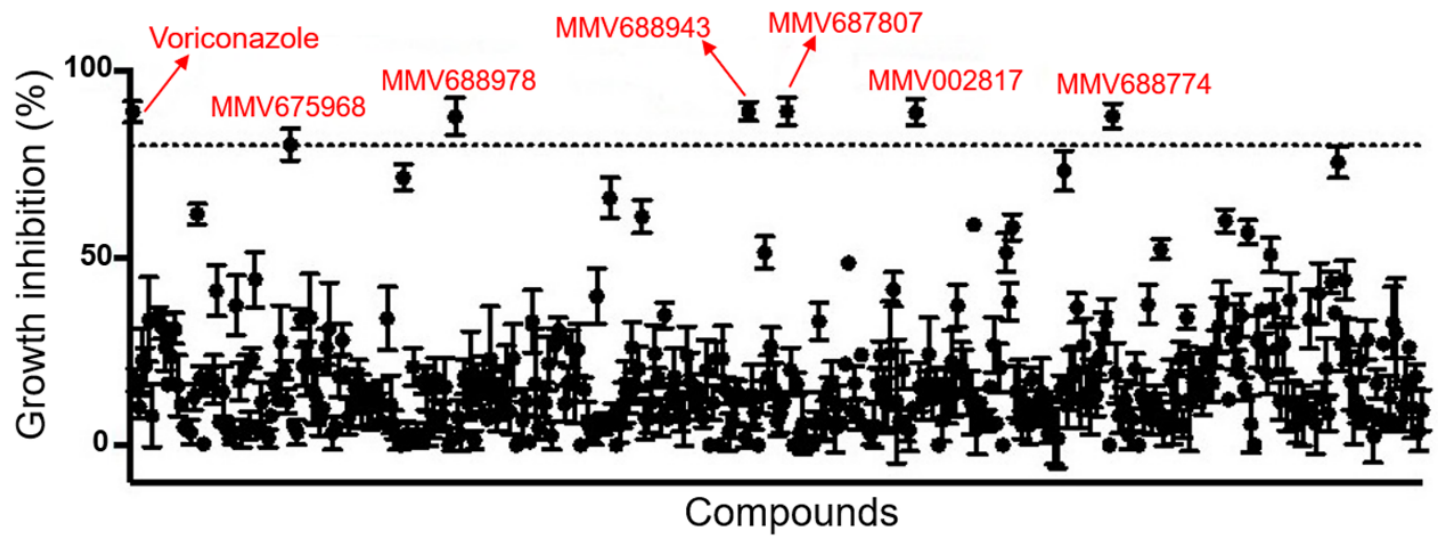

Figure 1. Screening of the Pathogen Box library. The total of 400 compounds were screened against S. aurantiacum CBS 136046. After incubation for $72 \mathrm{~h}$, fungal growth was quantified by optical density and those presenting at least $80 \%$ of inhibition (dotted line) were selected. Voriconazole was used as a positive control of inhibition.

The identification of these six compounds is presented in Table 1. Two of them are known antifungal drugs, difenoconazole, and posaconazole. Another two are noncommercial molecules, 5-Chloro-6-[(2,5-dimethoxyanilino)methyl]quinazoline-2,4-diamine (which has already been described with an anti-cryptosporidiosis activity) and $\mathrm{N}-[3,4-$ Bis(trifluoromethyl)phenyl]-5-chloro-2-hydroxybenzamide (which has already been described with an anti-tuberculosis activity). Finally, the last two compounds, auranofin and iodoquinol, are known drugs that are already used in clinical settings for the treatment of rheumatoid arthritis and amoebiasis, respectively.

Table 1. Identification of the selected compounds from the screening of the Pathogen Box library.

\begin{tabular}{|c|c|c|c|c|c|}
\hline Compound Code & $\%$ of Inhibition & Name & Antimicrobial Activity & Use & $\begin{array}{l}\text { Mechanism } \\
\text { of Action }\end{array}$ \\
\hline MMV675968 & 80.21779 & $\begin{array}{l}\text { 5-Chloro-6-[(2,5- } \\
\text { dimethoxyanilino) } \\
\text { methyl]quinazoline- } \\
\text { 2,4-diamine }\end{array}$ & $\begin{array}{c}\text { Sporothrix spp. } \\
\text { Candida albicans } \\
\text { Cryptosporidium parvum }\end{array}$ & $\begin{array}{l}\text { New compound (not } \\
\text { commercially } \\
\text { available) }\end{array}$ & $\begin{array}{l}\text { Disruption of } \\
\text { folate metabolism }\end{array}$ \\
\hline MMV688978 & 87.72361 & Auranofin & $\begin{array}{c}\text { Candida albicans } \\
\text { Cryptococcus neoformans } \\
\text { Blastomyces dermatitidis } \\
\text { Aspergillus fumigatus } \\
\text { Rhizopus oryzae } \\
\text { Chromoblastomycosis } \\
\text { agents } \\
\text { Entamoeba hystolitica } \\
\text { Staphylococcus aureus }\end{array}$ & Rheumatoid arthritis & $\begin{array}{l}\text { Inhibition of } \\
\text { thioredoxin reductase }\end{array}$ \\
\hline
\end{tabular}


Table 1. Cont

\begin{tabular}{cccccc}
\hline Compound Code & \% of Inhibition & Name & Antimicrobial Activity & Use & $\begin{array}{c}\text { Mechanism } \\
\text { of Action }\end{array}$ \\
\hline MMV688943 & 89.10369 & Difenoconazole & $\begin{array}{c}\text { Broad-range fungi } \\
\text { Trypanosoma cruzi }\end{array}$ & $\begin{array}{c}\text { Antifungal pesticide } \\
\text { (agrochemical) }\end{array}$ & $\begin{array}{c}\text { Inhibition of CYP51 } \\
\text { (ergosterol synthesis) }\end{array}$ \\
\hline MMV687807 & 89.10369 & $\begin{array}{c}\text { N-[3,4- } \\
\text { phenyl]-5-chloro-2- } \\
\text { hydroxybenzamide }\end{array}$ & Mycobacterium tuberculosis & $\begin{array}{c}\text { New compound (not } \\
\text { commercially } \\
\text { available) }\end{array}$ & $\begin{array}{c}\text { Salicylamide } \\
\text { analogue }\end{array}$ \\
MMV002817 & 88.82634 & Iodoquinol & $\begin{array}{c}\text { Chromoblastomycosis } \\
\text { agents } \\
\text { Candida auris } \\
\text { Entamoeba hystolitica }\end{array}$ & Amoebiasis & Ferrous ions chelate \\
\hline MMV688774 & 87.88809 & Posaconazole & Broad-range fungi & Antifungal agent & $\begin{array}{c}\text { Inhibition of CYP51 } \\
\text { (ergosterol synthesis) }\end{array}$ \\
\hline Reference drug & 81.84583 & Voriconazole & Broad-range fungi & Antifungal agent & $\begin{array}{c}\text { Inhibition of CYP51 } \\
\text { (ergosterol synthesis) }\end{array}$ \\
\hline
\end{tabular}

Considering that auranofin and iodoquinol are known drugs already used for other pathologies, we decided to select them for subsequent experiments due to their promising application as repurposing drugs to treat scedosporiosis and lomentosporiosis. The chemical structures of auranofin and iodoquinol are depicted in Figure 2.<smiles>CCP(CC)(CC)=NC[C@H]1O[C@H](COC(C)=O)[C@@H](OC(C)=O)[C@H](OC(C)=O)[C@@H]1OC(C)=O</smiles>

Auranofin<smiles>Oc1c(I)cc(I)c2cccnc12</smiles>

lodoquinol

Figure 2. Chemical structures of auranofin and iodoquinol.

3.2. Minimum Inhibitory Concentration of Auranofin and Iodoquinol against Different Scedosporium and Lomentospora Species

Since the screening of the Pathogen Box library was performed using only one concentration of each compound $(5 \mu \mathrm{m})$, we evaluated the MIC of auranofin and iodoquinol as well as that of voriconazole used as a reference drug. The assay was performed not only against $S$. aurantiacum, but also against other clinically relevant species, such as $S$. boydii, S. apiospermum, S. dehoogii, and L. prolificans.

Auranofin displayed MIC of $5 \mu \mathrm{m}$ for all five species tested and fungal viability was also inhibited at $5 \mu \mathrm{m}$, except for $S$. apiospermum whose viability was inhibited at $10 \mu \mathrm{m}$ (Table 2). Iodoquinol presented MIC values of $5 \mu \mathrm{m}$ for $S$. aurantiacum, $0.625 \mu \mathrm{m}$ for $S$. boydii and L. prolificans, and $1.25 \mu \mathrm{m}$ for S. apiospermum and $S$. dehoogii. Regarding the inhibition of fungal viability, iodoquinol was active at $5 \mu \mathrm{m}$ for S. aurantiacum and S. apiospermum, $0.625 \mu \mathrm{m}$ for $S$. boydii and L. prolificans, and $1.25 \mu \mathrm{m}$ for $S$. dehoogii (Table 2). 
Table 2. Minimum inhibitory concentration of auranofin, iodoquinol and voriconazole against several Scedosporium and Lomentospora species.

\begin{tabular}{|c|c|c|c|c|c|c|}
\hline \multirow[b]{2}{*}{ Fungal Species } & \multicolumn{2}{|c|}{ Auranofin $(\mu \mathrm{m})$} & \multicolumn{2}{|c|}{ Iodoquinol $(\mu \mathrm{m})$} & \multicolumn{2}{|c|}{ Voriconazole $(\mu \mathrm{m})$} \\
\hline & $\begin{array}{l}\text { Growth } \\
\text { Inhibition }\end{array}$ & $\begin{array}{l}\text { Viability } \\
\text { Inhibition }\end{array}$ & $\begin{array}{l}\text { Growth } \\
\text { Inhibition }\end{array}$ & $\begin{array}{l}\text { Viability } \\
\text { Inhibition }\end{array}$ & $\begin{array}{l}\text { Growth } \\
\text { Inhibition }\end{array}$ & $\begin{array}{c}\text { Viability } \\
\text { Inhibition }\end{array}$ \\
\hline S. aurantiacum & 5 & 5 & 5 & 5 & 3.75 & 3.75 \\
\hline S. boydii & 5 & 5 & 0.625 & 0.625 & 0.94 & 1.88 \\
\hline S. apiospermum & 5 & 10 & 1.25 & 5 & 3.75 & 7.5 \\
\hline S. dehoogii & 5 & 5 & 1.25 & 1.25 & 1.88 & 1.88 \\
\hline L. prolificans & 5 & 5 & 0.625 & 0.625 & 60 & 60 \\
\hline
\end{tabular}

Comparing these results with voriconazole, auranofin presented 12-fold lower MIC values for L. prolificans, whereas iodoquinol displayed lower values for most species (except for S. aurantiacum) (Table 2).

\subsection{Effect of Auranofin and Iodoquinol on Fungal Biofilms}

Auranofin and iodoquinol were also checked against biofilm formation and preformed biofilms of Scedosporium and Lomentospora species. Regarding preformed biofilms, auranofin decreased the fungal biomass about $50 \%$ of at $1 \times$ MIC for S. aurantiacum and $70 \%$ for S. dehoogii and L. prolificans. For S. boydii and S. apiospermum, a maximum inhibition of $40 \%$ was observed at $8 \times$ MIC (Figure $3 \mathrm{~A}$, Table S1). Extracellular matrix was reduced to $50 \%$ at $1 \times$ MIC for all fungi (Figure $3 \mathrm{~B}$, Table S1), and biofilm viability decreased to less than $50 \%$ at $1 \times$ MIC, reaching only $10 \%$ of viability at $8 \times$ MIC (Figure $3 \mathrm{C}$, Table S1).

A

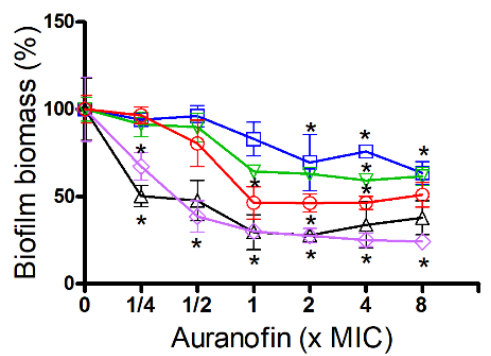

D

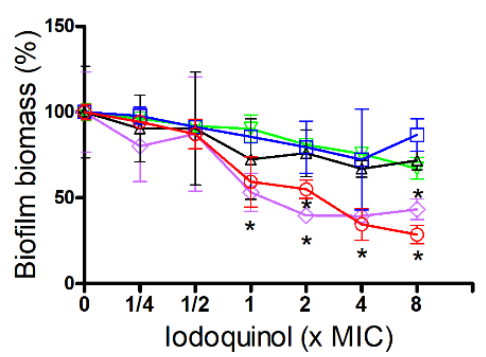

B

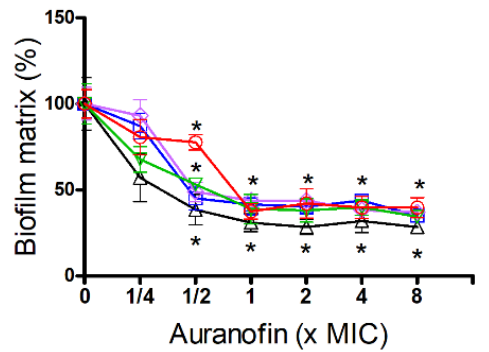

E

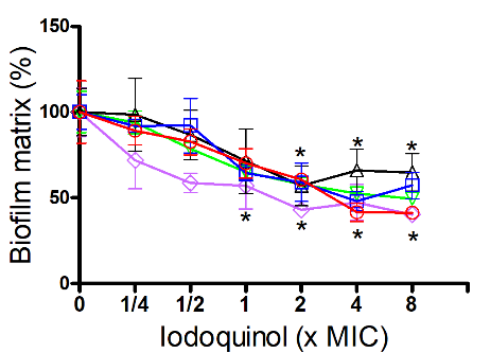

C

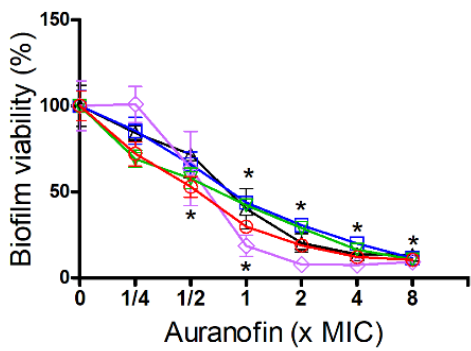

$\mathrm{F}$

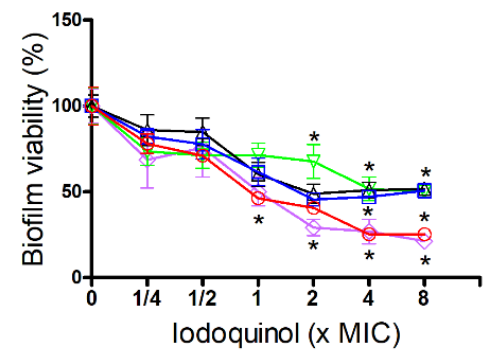

$\diamond$ L. prolificans $\forall$ S. apiospermum $\triangle$ S. dehoogii $\quad$ S. boydii $\rightarrow$ S. aurantiacum

Figure 3. Effect of auranofin (A-C) and iodoquinol (D-F) on preformed biofilms of Scedosporium and Lomentospora species. Fungal biofilm was firstly formed in RPMI 1640 medium for $24 \mathrm{~h}$ and then it was treated with different concentrations of auranofin or iodoquinol for another $24 \mathrm{~h}$ incubation. Fungal biomass (A,D), extracellular matrix $(\mathbf{B}, \mathbf{E})$ and viability $(\mathbf{C}, \mathbf{F})$ were measured using violet crystal, safranin and XTT-reduction assay, respectively. ${ }^{*} p<0.01$, compared to 0 (absence of drug) for each species. 
Iodoquinol did not reduce the biomass of preformed biofilms of S. boydii, S. apiospermum and S. dehoogii, but a reduction of more than $50 \%$ was observed for S. aurantiacum and L. prolificans at $4 \times$ MIC (Figure 3D, Table S1). Extracellular matrix was decreased about $50 \%$ at $4 \times$ MIC, except for $S$. dehoogii, whose matrix was reduced only $35 \%$ at $4 \times$ MIC (Figure 3E, Table S1). Biofilm viability was 50\% decreased at $2 \times$ MIC for S. boydii and S. dehoogii, and $4 \times$ MIC for S. apiospermum. For S. aurantiacum and L. prolificans, biofilm viability was found to be only $30 \%$ at $2 \times$ MIC and $20 \%$ at $8 \times$ MIC (Figure $3 F$, Table S1). All data suggest that both compounds, auranofin and iodoquinol, were able to affect mature biofilms, especially their viability.

Regarding the biofilm formation, a stronger overall effect was observed for both compounds. Auranofin caused $90 \%$ inhibition of biomass and extracellular matrix formation, as well as viability for all five species, except for $L$. prolificans whose viability was maintained between $30-50 \%$ at 1-8 $\times$ MIC (Figure 4 A-C, Table S2). Considering iodoquinol, $1 \times$ MIC caused $90 \%$ inhibition of biomass and extracellular matrix formation, and viability for S. apiospermum, S. dehoogii, and L. prolificans (except the viability of L. prolificans, which was $75 \%$ inhibited at $8 \times$ MIC) (Figure $4 \mathrm{D}-\mathrm{F}$, Table S2). For S. aurantiacum and S. boydii, similar effects were only observed at $2 \times$ MIC (Figure 4 D-F, Table S2).

A

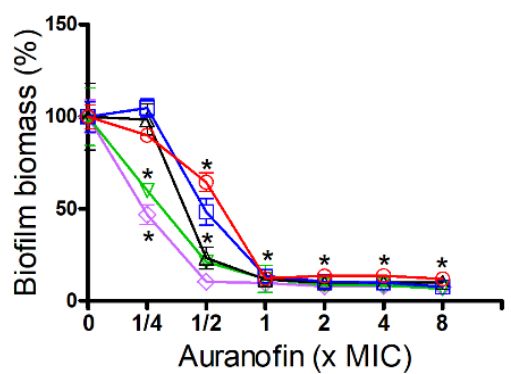

D

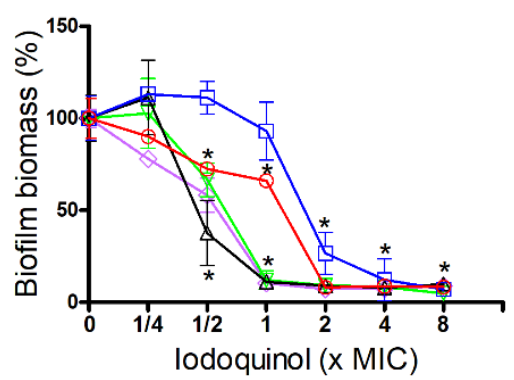

B

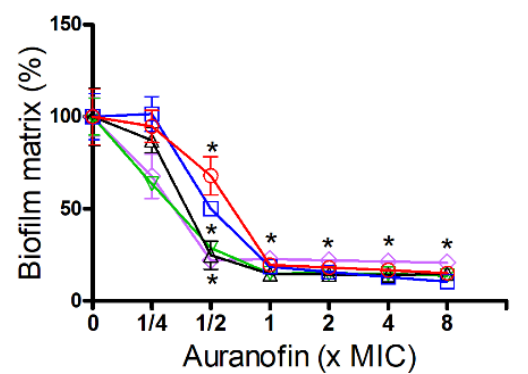

$\mathrm{E}$

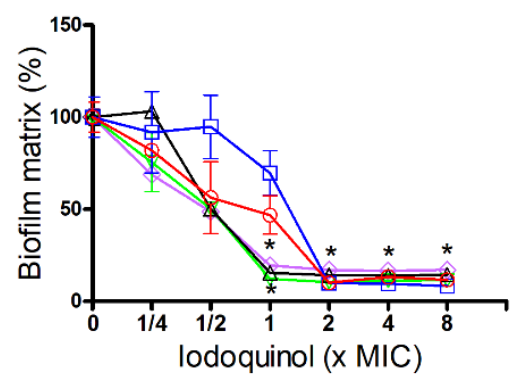

C

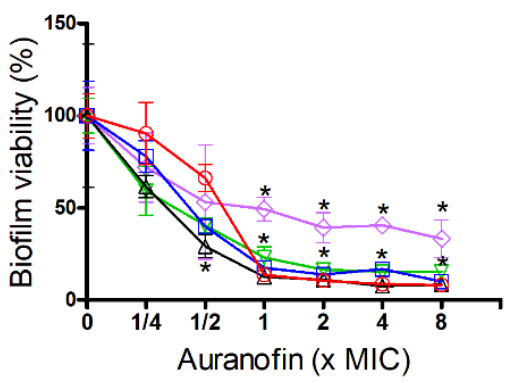

$\mathrm{F}$

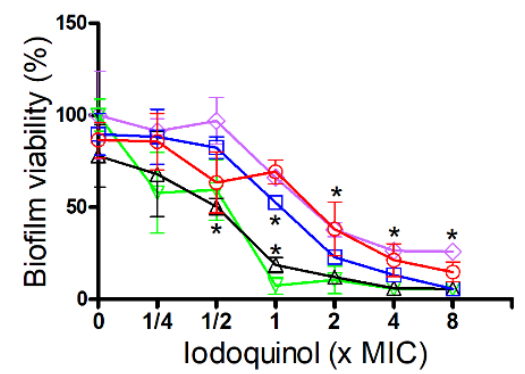

$\diamond$ L. prolificans $\forall$ S. apiospermum $\triangle$ S. dehoogii $\quad$ S. boydii $\ominus$ S. aurantiacum

Figure 4. Effect of auranofin (A-C) and iodoquinol (D-F) on biofilm formation of Scedosporium and Lomentospora species. Fungal cells were adhered on polystyrene surface for $1.5 \mathrm{~h}$ and then different concentrations of auranofin or iodoquinol were added. Fungal biomass $(\mathbf{A}, \mathbf{D})$, extracellular matrix $(\mathbf{B}, \mathbf{E})$ and viability $(\mathbf{C}, \mathbf{F})$ were measured using violet crystal, safranin and XTT-reduction assay, respectively. ${ }^{*} p<0.01$, compared to 0 (absence of drug) for each species.

All these data suggest that both auranofin and iodoquinol displayed a more drastic effect on biofilm formation compared to mature ones.

\subsection{Alterations Caused by Auranofin and Iodoquinol on S. aurantiacum Morphology}

Considering that auranofin and iodoquinol presented interesting antifungal activity against planktonic cells and biofilms of different Scedosporium and Lomentospora species, we 
evaluated the alterations caused by both drugs on fungal morphology through scanning electron microscopy (SEM). S. aurantiacum was used as a reference species.

SEM analysis revealed that untreated S. aurantiacum had septated hyphae (Figure 5A,B) with sympodial conidia showing an ellipsoidal shape (Figure 6A,B). The treatment of S. aurantiacum with $2.5 \mu \mathrm{m}$ auranofin $(0.5 \times \mathrm{MIC})$ induced alterations in the fungal cell wall integrity (Figure 5C,D), while the treatment with iodoquinol also disrupts the cell wall (Figure 6C,D) and increases the thickness of conidia (Figure 6E).
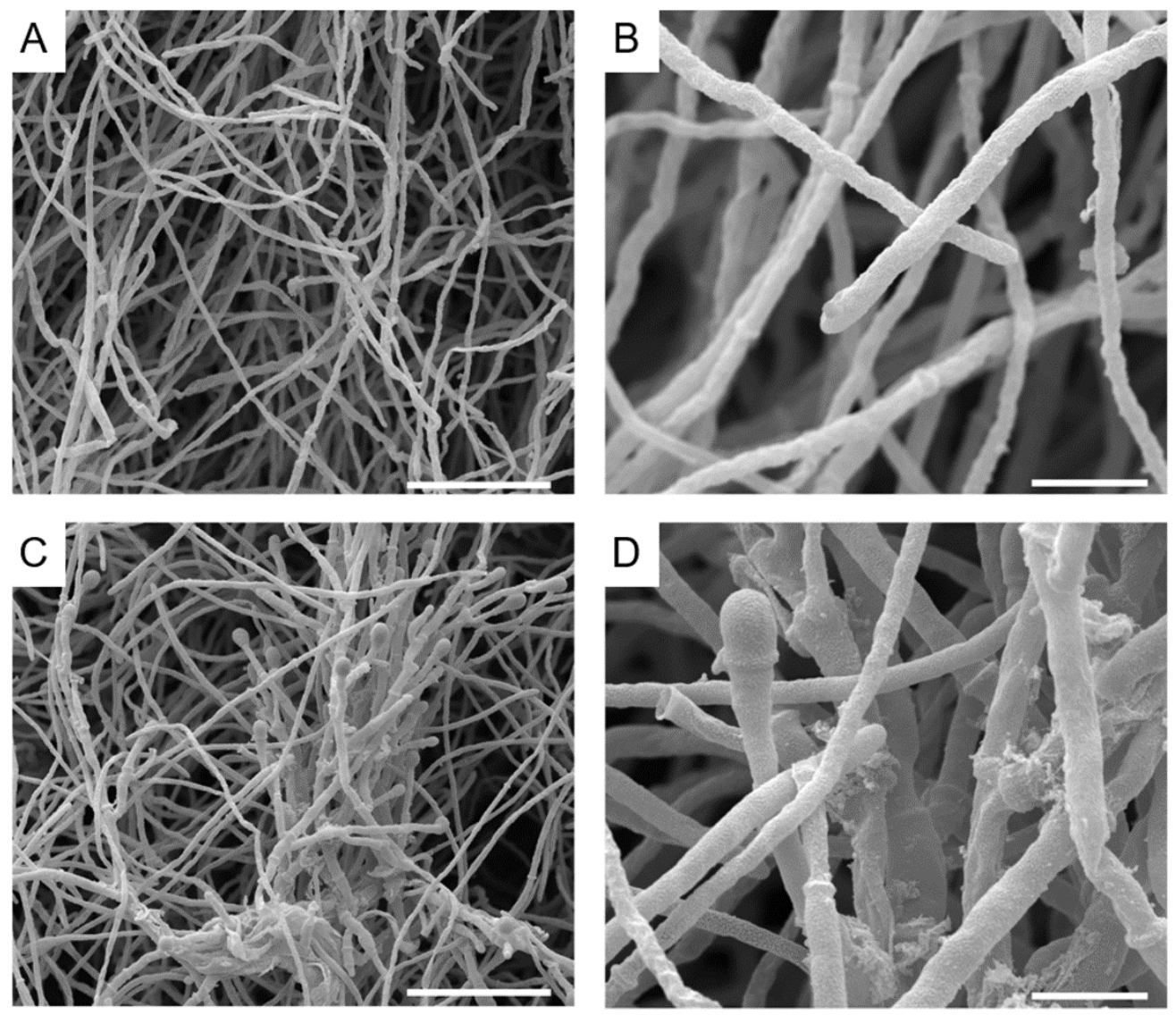

Figure 5. Ultrastructural alterations of S. aurantiacum CBS 136046 on exposure to auranofin, evaluated by scanning electron microscopy. Untreated cells exhibit septated hyphae (A,B), while samples treated with $2.5 \mu \mathrm{m}$ auranofin for $48 \mathrm{~h}$ show alterations in fungal surface (C,D). Bars: $25 \mu \mathrm{m}(\mathbf{A}, \mathbf{C})$ e $5 \mu \mathrm{m}(\mathbf{B}, \mathbf{D})$.

\subsection{Drug Interaction among Auranofin and Iodoquinol with Fluconazole, Voriconazole and Caspofungin}

To evaluate the interaction properties of auranofin and iodoquinol with some current antifungal drugs used in clinical settings, a synergy analysis was performed. Once again, S. aurantiacum was used as a representative species. Drug interaction was analyzed between auranofin or iodoquinol with fluconazole, voriconazole, or caspofungin.

The MIC observed for fluconazole was reduced two-fold and four-fold after coincubation with auranofin and iodoquinol, respectively, while MIC for voriconazole was reduced two-fold when combined with iodoquinol. The decrease in the caspofungin MEC was more prominent after combination with iodoquinol (16-fold), but it was also observed with auranofin (4-fold) (Table 3). Following the FIC index criteria, a synergism effect was observed between iodoquinol and caspofungin $(\mathrm{FICI}=0.18)($ Table 3$)$. 

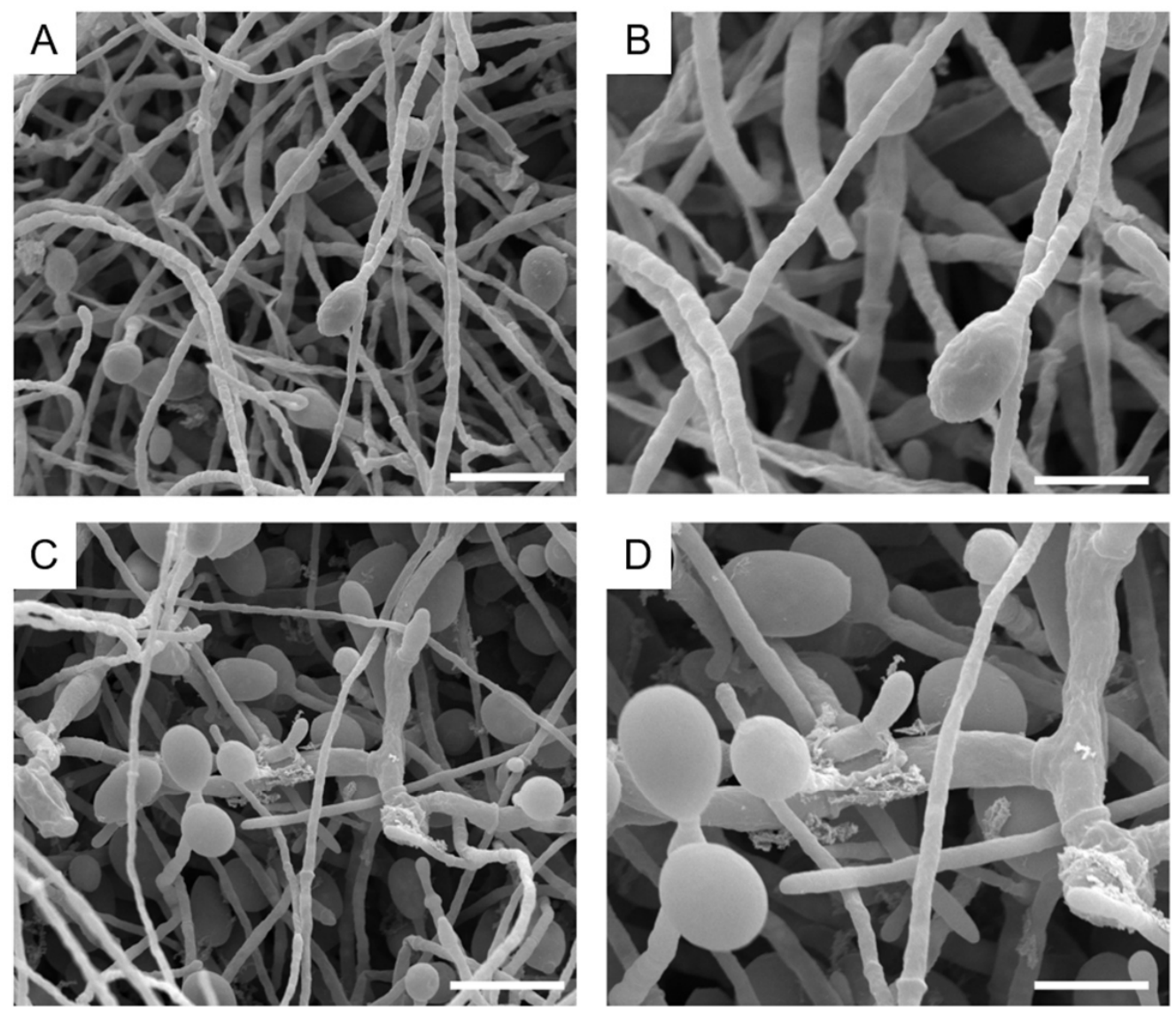

E

Conidia

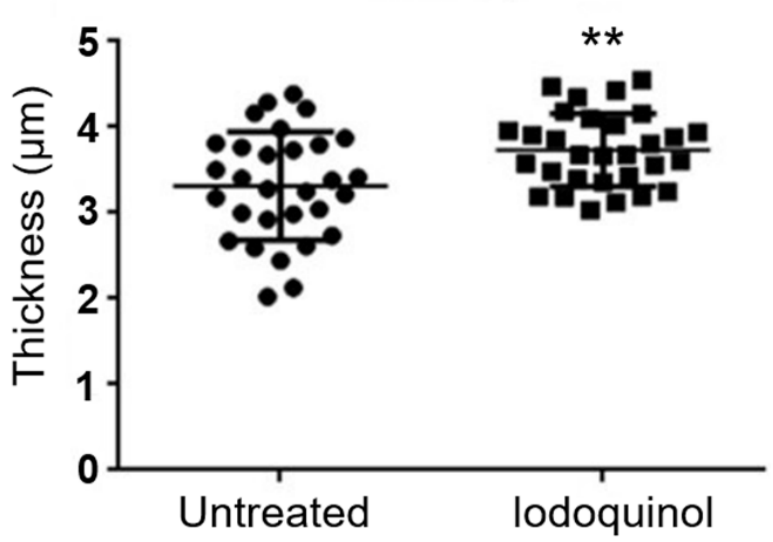

Figure 6. S. aurantiacum CBS 136046 alterations after treatment with iodoquinol, evaluated by scanning electron microscopy. Untreated cells exhibit sympodial conidia with ellipsoidal shape (A,B), while samples treated with $1.25 \mu \mathrm{m}$ iodoquinol for $48 \mathrm{~h}$ show disruption of the cell wall (C,D) and increase in conidia thickness (E). Bars: $25 \mu \mathrm{m}(\mathbf{A}, \mathbf{C})$ e $5 \mu \mathrm{m}(\mathbf{B}, \mathbf{D}) .{ }^{* *} p<0.01$.

In addition, a greater reduction in fungal viability after a combination of auranofin and iodoquinol with antifungal drugs was detected, compared with the activity observed using the same concentration of antifungal alone. Auranofin increased the caspofungin activity at 1.25 and $2.5 \mu \mathrm{m}(0.25$ and $0.5 \times$ MIC, respectively $)$, whereas it increased the fluconazole and voriconazole activities at $2.5 \mu \mathrm{m}(0.5 \times \mathrm{MIC})$ (Figure $7 \mathrm{~A})$. Iodoquinol also potentiates the effectiveness of caspofungin (at all tested concentrations), fluconazole, and voriconazole (at $2.5 \mu \mathrm{m})$ (Figure 7B). 
Table 3. Antifungal activity of auranofin, iodoquinol, fluconazole, voriconazole and caspofungin-Alone and in combinations according to Fractional Inhibitory Concentration Index-against S. aurantiacum CBS 136046. MIC values were used to analyze the interaction between auranofin and iodoquinol with azoles (fluconazole and voriconazole), whereas MEC values were used to assess the interaction between auranofin and iodoquinol with caspofungin.

\begin{tabular}{cccccc}
\hline & MIC $_{\mathbf{8 0}} / \mathbf{M E C}_{\mathbf{8 0}}$ Alone $(\mu \mathrm{m})$ & MIC $_{\mathbf{8 0}} / \mathbf{M E C}_{\mathbf{8 0}}$ Combined $_{(\mu \mathrm{m})}$ & \multicolumn{2}{c}{ FIC Index } \\
\hline Auranofin & 5 & Aur/Flc & $2.5 / 80$ & Aur/Flc & 1.0 (no effect) \\
\hline Iodoquinol & 5 & Aur/Vori & $5 / 3.75$ & Aur/Vori & 2.0 (no effect) \\
\hline Fluconazole & 160 & Aur/Casp & $2.5 / 5.0$ & Aur/Casp & 0.75 (no effect) \\
\hline Voriconazole & 3.75 & Iodo/Flc & $2.5 / 40$ & Iodo/Flc & 0.75 (no effect) \\
\hline Caspofungin & 20 & Iodo/Vori & $2.5 / 1.87$ & Iodo/Vori & 1.0 (no effect) \\
\hline & & Iodo/Casp & $0.62 / 1.25$ & Iodo/Casp & 0.18 (synergic) \\
\hline
\end{tabular}

MIC: Minimal inhibitory concentration; MEC: Minimum effective concentration; FIC: fractional inhibitory concentration; Aur: auranofin; Iodo: iodoquinol; Flc: fluconazole; Vori: voriconazole; Casp: caspofungin.

A

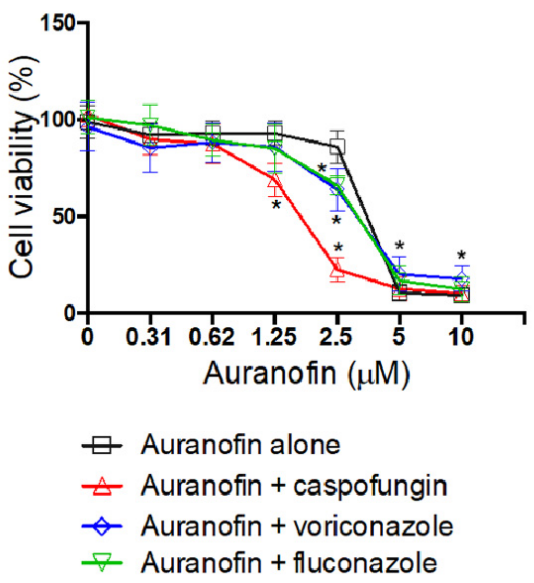

B

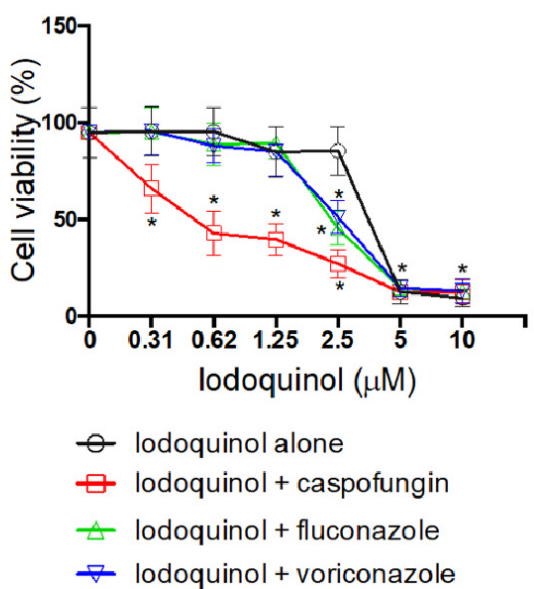

Figure 7. Effect of auranofin (A) and iodoquinol (B) either alone or in combination with caspofungin, fluconazole and voriconazole against $S$. aurantiacum CBS 136046. Viability was measured using XTT-reduction assay after $72 \mathrm{~h}$ of incubation. ${ }^{*} p<0.01$.

Regarding the analysis using the Bliss independence method, auranofin presented a synergistic effect when combined with caspofungin and, to a low extent, with fluconazole and voriconazole (Table 4). Iodoquinol displayed synergistic interaction only with caspofungin (Table 4).

Table 4. Antifungal activity of auranofin, iodoquinol, fluconazole, voriconazole and caspofungin-Alone and in combinations according to the Bliss independence model.

Efficacy of Combined Drugs

\begin{tabular}{|c|c|c|c|c|c|c|c|c|}
\hline & & & \multicolumn{6}{|c|}{ Efficacy of Combined Drugs } \\
\hline & \multicolumn{2}{|c|}{$\begin{array}{c}\text { Efficacy of Drugs Alone } \\
\text { (\% of Inhibition) }\end{array}$} & \multicolumn{3}{|c|}{ Auranofin } & \multicolumn{3}{|c|}{ Iodoquinol } \\
\hline & $\mathrm{MIC}_{80}$ & $0.5 \times \mathrm{MIC}_{80}$ & $E_{\text {obs }}$ & $E_{\exp }$ & $\begin{array}{c}\Delta E, \% \\
\text { (Interaction) }\end{array}$ & $E_{\mathrm{obs}}$ & $E_{\exp }$ & $\begin{array}{c}\Delta E, \% \\
\text { (Interaction) }\end{array}$ \\
\hline Auranofin & 87.72 & 20.28 & NP & NP & NP & NP & NP & NP \\
\hline Iodoquinol & 88.82 & 44.15 & NP & NP & NP & NP & $\mathrm{NP}$ & NP \\
\hline Fluconazole & 82.79 & 30.64 & 81.72 & 67.93 & $13.79(S)$ & 21.14 & 51.77 & $-30.69(\mathrm{~A})$ \\
\hline Voriconazole & 81.84 & 49.75 & 57 & 55.71 & $1.29(\mathrm{~S})$ & 86.77 & 89.96 & $-3.19(\mathrm{~A})$ \\
\hline Caspofungin & 89.39 & 16.57 & 86.78 & 49.82 & $36.96(S)$ & 87.30 & 73.34 & $13.96(S)$ \\
\hline
\end{tabular}

MIC: Minimal inhibitory concentration. $E_{\mathrm{obs}}$, efficacy observed in the analysis. $E_{\text {exp }}$, efficacy expected according to Bliss calculation. $\Delta E$, difference between $E_{\mathrm{obs}}$ and $E_{\mathrm{exp}}$. NP, not performed. 


\section{Discussion}

Scedosporiosis is a widespread infection that affects healthy and immunocompromised patients, causing superficial and invasive infections, respectively [3]. Scedosporiosis is associated with a variety of base conditions, such as cancer, hematological malignancies, organ transplantation, and AIDS [3,53,54]. The mortality rate reaches $75 \%$ in HIV patients [55]. In addition, Scedosporium and Lomentospora pathogens are known as one of the most frequent fungi colonizing lungs of cystic fibrosis patients $[6,56]$.

Scedosporium and Lomentospora species are resistant to the most frequently administered antifungal agents, such as amphotericin B and different azoles and echinocandins [10]. In this context, $S$. aurantiacum has revealed itself as a highly virulent and resistant species [57], which is one reason why it was chosen as a representative species for the screening of the Pathogen Box library. Considering the concerns raised by Scedosporium pathogens in clinical settings, which include the hard-to-treat aspect of scedosporiosis and the high mortality levels especially in immunocompromised patients, the study of new treatment alternatives is an urgent need.

In the present study, we screened the Pathogen Box library against S. aurantiacum as a representative species of Scedosporium and Lomentospora group. This library was developed by the Medicines for Malaria Venture organization, which contains 400 compounds including new molecules and repurposing potential drugs (https:/ /www.mmv.org/mmv-open/ pathogen-box) (accessed on 3 August 2021). Pathogen Box was developed to comprise promising compounds that might be active against pathogens associated with neglected diseases [37], which makes it a useful tool to search for new treatment alternatives for fungal infections.

Our screening revealed six compounds that displayed at least $80 \%$ inhibition against S. aurantiacum. Two known antifungal drugs (difenoconazole and posaconazole), two new molecules (MMV675968 and MMV687807), and two drugs already used for other pathologies (auranofin and iodoquinol). Pathogen Box has also been screened for other pathogenic fungi, such as Candida, Cryptococcus, and Sporothrix species, as well as chromoblastomycosis agents [38-42]. These studies observed that MMV675968 and MMV687807 were also active against Candida albicans and Sporothrix species [38,42], auranofin inhibited C. albicans and chromoblastomycosis agents [38,41], and iodoquinol displayed antifungal activity against Sporothrix species, chromoblastomycosis agents, and Candida auris [40-42]. Considering the potential of auranofin and iodoquinol to be used as a repurposing approach to treat fungal infections, we decided to select these two molecules to continue our analyses.

As mentioned above, auranofin and iodoquinol have already been evaluated against other pathogenic fungi. Whereas the antifungal activity of iodoquinol has only been demonstrated recently by studies using the Pathogen Box [40-42,58], the antifungal effect of auranofin has already been described in the literature for a variety of fungal pathogens, such as Candida species, C. neoformans, Blastomyces dermatitidis, Aspergillus fumigatus, and Rhizopus oryzae $[59,60]$. It has also been shown that auranofin is a promising repurposing drug to treat Scedosporium and Lomentospora infections, presenting minimal inhibitory concentrations ranging from 2 to $>16 \mu \mathrm{g} / \mathrm{mL}$ [61].

Auranofin and iodoquinol presented antifungal activity not only against $S$. aurantiacum, but also against other species, suggesting that both drugs displayed a conserved effect in Scedosporium and Lomentospora group. In addition, auranofin displayed an anti-biofilm effect against different species of Scedosporium and Lomentospora groups, whereas iodoquinol was less active especially against preformed biofilms. In C. albicans, auranofin also displayed anti-biofilm activity $[62,63]$, suggesting that it might be effective not only against planktonic growth, but also with adherent cells. Regarding iodoquinol, it also presented low activity against the preformed biofilm of $C$. auris [40], suggesting that more studies are needed to clarify the effect of this molecule on fungal biofilms.

SEM analysis revealed fungal surface alterations when S. aurantiacum was exposed to auranofin. Its mechanism of action is described to involve the inhibition of small redox proteins called thioredoxin reductases (TrxR), which are responsible for maintaining a 
reduced cellular environment [64]. TrxR is present in a variety of cell models, such as mammalian cells, protozoans, bacteria, plants, and fungi, and its inhibition by auranofin has already been demonstrated in different cell models, including Entoameba histolytica, Staphylococcus aureus, and fungi $[63,64]$. Auranofin has already been shown to primarily inhibit TrxR by irreversible binding to the selenocysteinyl residue, but its exact mode of action is still unclear [61]. In fungi, TrxR was found to be essential for C. neoformans viability and to play a role in responding to oxidative stress in C. albicans, Saccharomyces cerevisiae, and A. fumigatus. Thus, its inhibition by auranofin leads to a higher fungal sensitivity to oxidative stress $[59,64]$. Scedosporium species are known to possess more than 30 genes encoding putative antioxidant enzymes, especially those encoding TrxRs, which is one reason for their high resistance to antifungal agents [61]. Thus, its inhibition by auranofin might be an important mechanism of action and a promising approach to impair Scedosporium growth.

Iodoquinol is a hydroxyquinoline used to treat Amoeba infections [40,42]. Its mechanism of action is based on chelating ferrous ions essential for microbial metabolism [65]. Nevertheless, little is known about alterations induced in fungal cells. In Sporothrix species, cells treated with iodoquinol presented a ruptured plasma membrane and leakage of intracellular content, suggesting that the cell surface is affected [42]. Scedosporium cell surface was also affected after iodoquinol exposure. In addition, an increase in neutral lipid content and in cell size were observed [42], similar to what we found by SEM analysis where iodoquinol-treated cells presented thicker conidia compared to control.

Besides the direct antifungal effect of new compounds, the study of their interactions with the current antifungal agents is valuable to check the possibility to improve treatment as a combined therapy. Our results demonstrated that auranofin and iodoquinol increased the antifungal activity of caspofungin, fluconazole, and voriconazole. In addition, a synergistic effect was observed between iodoquinol and caspofungin. In C. albicans and C. neoformans, an additive effect of auranofin with fluconazole and amphotericin B has already been demonstrated [62], and an additive interaction has been found with voriconazole in Scedosporium and Lomentospora species [61]. However, these observations were detected only against a limited number of isolates, indicating that more studies are needed to understand how auranofin interacts with the antifungal drugs currently available in clinical settings. Regarding iodoquinol, little is known about its interaction with other antifungal drugs. Coelho and colleagues demonstrated that no effect is observed with itraconazole and terbinafine against fungi causing chromoblastomycosis [41]. On the other hand, topical formulations of iodoquinol exhibited antifungal properties to treat dermatoses caused by C. albicans, Malassezia spp., and dermatophytes and could be used as topical therapy associated with oral antifungals $[41,42]$.

The Bliss independence model is a probabilistic interpretation of drug interactions and is a well-used method to study the synergism or antagonism of two combined drugs [66,67]. Our data revealed that auranofin displays a synergistic effect with all three antifungal drugs tested. Although presenting distinct results compared to FICI analysis, Bliss independence data corroborated what was observed in terms of fungal viability presented in Figure 7. Regarding iodoquinol, its interaction with caspofungin was synergistic using both FICI and Bliss independence analysis. On the other hand, its interaction with azoles was found to be indifference using FICI and antagonistic in Bliss independence model. These data indicate that the definition of synergy is controversial and varies according to which method is used, suggesting that further and deeper studies are needed to clarify the interactions between auranofin and iodoquinol with the antifungal agents currently used in clinical settings.

The cytotoxicity of auranofin and iodoquinol is a key point for the use of these drugs in clinical settings for the treatment of fungal infections. In vitro analyses have already shown that cytotoxicity of auranofin varies significantly depending on the cell model, ranging from 0.15 to $6.38 \mu \mathrm{m}$ [68-72]. However, since auranofin is a drug already used in humans to treat rheumatoid arthritis, it is important to consider the observations found in clinical trials. In this context, side effects related to the use of auranofin are considered rare and the most 
frequent is associated with gastrointestinal disorders such as diarrhea [68]. In addition, these side effects are associated with the long-term use of auranofin to treat rheumatoid arthritis, which requires years of drug administration [73,74]. Thus, it is believed that auranofin toxicity would not impair its use against fungal infections, since it requires a short administration.

Regarding iodoquinol, in vitro cytotoxicity also varies significantly in the literature and ranges from 2.5 to more than $125 \mu \mathrm{m}$ [42,75]. Side effects are also rare and associated with higher doses and prolonged administration, where patients present headaches, nausea, and vomiting $[42,65,76]$.

In summary, screening of the Pathogen Box library allowed for the identification of two new molecules presenting antifungal activity, as well as two promising repurposing compounds (auranofin and iodoquinol), which were evaluated in more detail in the present study. Considering the results that showed their effects against Scedosporium and Lomentospora species and all the data found in the literature, both compounds are potent candidates for more studies on their use to treat fungal infections, alone or in combination with other antifungal agents.

Supplementary Materials: The following are available online at https: / www.mdpi.com/article / 10.3390/jof7100803/s1, Table S1: Inhibition percentage of preformed biofilms of Scedosporium and Lomentospora species by auranofin and iodoquinol., Table S2: Inhibition percentage of biofilms formation of Scedosporium and Lomentospora species by auranofin and iodoquinol.

Author Contributions: Conceptualization, R.R.-P. and L.P.B.-S.; methodology, R.R.-P., L.P.B.-S., M.I.D.d.S.X., Y.d.C.-A. and V.P.R.; software, R.R.-P., L.P.B.-S., M.I.D.d.S.X., Y.d.C.-A. and V.P.R.; validation, R.R.-P. and L.P.B.-S.; formal analysis, R.R.-P. and L.P.B.-S.; investigation, R.R.-P., L.P.B.-S., M.I.D.d.S.X., Y.d.C.-A. and V.P.R.; resources, S.R. and E.B.-B.; data curation, R.R.-P., L.P.B.-S., M.I.D.d.S.X., Y.d.C.-A. and V.P.R.; writing-original draft preparation, R.R.-P.; writing-review and editing, L.P.B.-S., S.R. and E.B.-B.; visualization, R.R.-P.; supervision, S.R. and E.B.-B.; project administration, S.R. and E.B.-B.; funding acquisition, S.R. and E.B.-B. All authors have read and agreed to the published version of the manuscript.

Funding: This study was supported by the Coordenação de Aperfeiçoamento de Pessoal de Nível Superior-Brasil (CAPES)—Finance Code 001; Conselho Nacional de Desenvolvimento Científico e Tecnológico (CNPq) and Fundação de Amparo à Pesquisa do Estado do Rio de Janeiro (Faperj).

Institutional Review Board Statement: Not applicable.

Informed Consent Statement: Not applicable.

Data Availability Statement: Not applicable.

Acknowledgments: The authors thank Walter Martin Oelemann for kindly revise the English grammar of the text and the Centro Nacional de Biologia Estrutural e Bioimagem (Cenabio) for the use of scanning electron microscope.

Conflicts of Interest: The authors declare no conflict of interest.

\section{References}

1. Brown, G.D.; Denning, D.W.; Gow, N.A.; Levitz, S.M.; Netea, M.G.; White, T.C. Hidden killers: Human fungal infections. Sci. Transl. Med. 2012, 4, 165rv113. [CrossRef] [PubMed]

2. Bongomin, F.; Gago, S.; Oladele, R.O.; Denning, D.W. Global and Multi-National Prevalence of Fungal Diseases-Estimate Precision. J. Fungi 2017, 3, 57. [CrossRef] [PubMed]

3. Cortez, K.J.; Roilides, E.; Quiroz-Telles, F.; Meletiadis, J.; Antachopoulos, C.; Knudsen, T.; Buchanan, W.; Milanovich, J.; Sutton, D.A.; Fothergill, A.; et al. Infections caused by Scedosporium spp. Clin. Microbiol. Rev. 2008, 21, 157-197. [CrossRef] [PubMed]

4. Gilgado, F.; Cano, J.; Gene, J.; Serena, C.; Guarro, J. Different virulence of the species of the Pseudallescheria boydii complex. Med. Mycol. 2009, 47, 371-374. [CrossRef]

5. Luplertlop, N. Pseudallescheria/Scedosporium complex species: From saprobic to pathogenic fungus. J. Mycol. Med. 2018, 28, 249-256. [CrossRef] [PubMed]

6. $\quad$ Engel, T.G.P.; Slabbers, L.; de Jong, C.; Melchers, W.J.G.; Hagen, F.; Verweij, P.E.; Merkus, P.; Meis, J.F. Dutch Cystic Fibrosis Fungal Collection, C. Prevalence and diversity of filamentous fungi in the airways of cystic fibrosis patients-A Dutch, multicentre study. J. Cyst. Fibros. 2019, 18, 221-226. [CrossRef] 
7. Cowen, L.E. The evolution of fungal drug resistance: Modulating the trajectory from genotype to phenotype. Nat. Rev. Microbiol. 2008, 6, 187-198. [CrossRef]

8. Rollin-Pinheiro, R.; Singh, A.; Barreto-Bergter, E.; Del Poeta, M. Sphingolipids as targets for treatment of fungal infections. Future Med. Chem. 2016, 8, 1469-1484. [CrossRef]

9. Ramirez-Garcia, A.; Pellon, A.; Rementeria, A.; Buldain, I.; Barreto-Bergter, E.; Rollin-Pinheiro, R.; de Meirelles, J.V.; Xisto, M.; Ranque, S.; Havlicek, V.; et al. Scedosporium and Lomentospora: An updated overview of underrated opportunists. Med. Mycol. 2018, 56, 102-125. [CrossRef]

10. Lackner, M.; de Hoog, G.S.; Verweij, P.E.; Najafzadeh, M.J.; Curfs-Breuker, I.; Klaassen, C.H.; Meis, J.F. Species-specific antifungal susceptibility patterns of Scedosporium and Pseudallescheria species. Antimicrob. Agents Chemother. 2012, 56, 2635-2642. [CrossRef]

11. Sedlacek, L.; Graf, B.; Schwarz, C.; Albert, F.; Peter, S.; Wurstl, B.; Wagner, S.; Klotz, M.; Becker, A.; Haase, G.; et al. Prevalence of Scedosporium species and Lomentospora prolificans in patients with cystic fibrosis in a multicenter trial by use of a selective medium. J. Cyst. Fibros. 2015, 14, 237-241. [CrossRef]

12. Tortorano, A.M.; Richardson, M.; Roilides, E.; van Diepeningen, A.; Caira, M.; Munoz, P.; Johnson, E.; Meletiadis, J.; Pana, Z.-D.; Lackner, M.; et al. ESCMID and ECMM joint guidelines on diagnosis and management of hyalohyphomycosis: Fusarium spp., Scedosporium spp. and others. Clin. Microbiol. Infect. 2014, 20, 27-46. [CrossRef]

13. Pellon, A.; Ramirez-Garcia, A.; Buldain, I.; Antoran, A.; Martin-Souto, L.; Rementeria, A.; Hernando, F.L. Pathobiology of Lomentospora prolificans: Could this species serve as a model of primary antifungal resistance? Int. J. Antimicrob. Agents 2018, 51, 10-15. [CrossRef]

14. Hoenigl, M.; Salmanton-García, J.; Walsh, T.J.; Nucci, M.; Neoh, C.F.; Jenks, J.D.; Lackner, M.; Sprute, R.; Al-Hatmi, A.M.S.; Bassetti, M.; et al. Global guideline for the diagnosis and management of rare mould infections: An initiative of the European Confederation of Medical Mycology in cooperation with the International Society for Human and Animal Mycology and the American Society for Microbiology. Lancet Infect. Dis. 2021, 21, e246-e257. [CrossRef]

15. Seidel, D.; Meißner, A.; Lackner, M.; Piepenbrock, E.; Salmanton-García, J.; Stecher, M.; Mellinghoff, S.; Hamprecht, A.; Durán Graeff, L.; Köhler, P.; et al. Prognostic factors in 264 adults with invasive Scedosporium spp. and Lomentospora prolificans infection reported in the literature and FungiScope ${ }^{\circledR}$. Crit. Rev. Microbiol. 2019, 45, 1-21. [CrossRef] [PubMed]

16. Rodriguez-Tudela, J.L.; Berenguer, J.; Guarro, J.; Kantarcioglu, A.S.; Horre, R.; de Hoog, G.S.; Cuenca-Estrella, M. Epidemiology and outcome of Scedosporium prolificans infection, a review of 162 cases. Med. Mycol. 2009, 47, 359-370. [CrossRef] [PubMed]

17. Esquivel, B.D.; Rybak, J.M.; Barker, K.S.; Fortwendel, J.R.; Rogers, P.D.; White, T.C. Characterization of the Efflux Capability and Substrate Specificity of Aspergillus fumigatus PDR5-like ABC Transporters Expressed in Saccharomyces cerevisiae. mBio 2020, 11, 1-16. [CrossRef]

18. Bhattacharya, S.; Sobel, J.D.; White, T.C. A Combination Fluorescence Assay Demonstrates Increased Efflux Pump Activity as a Resistance Mechanism in Azole-Resistant Vaginal Candida albicans Isolates. Antimicrob. Agents Chemother. 2016, 60, 5858-5866. [CrossRef] [PubMed]

19. Bhattacharya, S.; Holowka, T.; Orner, E.P.; Fries, B.C. Gene Duplication Associated with Increased Fluconazole Tolerance in Candida auris cells of Advanced Generational Age. Sci. Rep. 2019, 9, 5052. [CrossRef]

20. Niimi, M.; Firth, N.A.; Cannon, R.D. Antifungal drug resistance of oral fungi. Odontology 2010, 98, 15-25. [CrossRef] [PubMed]

21. Hampe, I.A.I.; Friedman, J.; Edgerton, M.; Morschhäuser, J. An acquired mechanism of antifungal drug resistance simultaneously enables Candida albicans to escape from intrinsic host defenses. PLoS Pathog. 2017, 13, e1006655. [CrossRef] [PubMed]

22. Vanden Bossche, H.; Marichal, P.; Gorrens, J.; Bellens, D.; Moereels, H.; Janssen, P.A. Mutation in cytochrome P-450-dependent 14 alpha-demethylase results in decreased affinity for azole antifungals. Biochem. Soc. Trans. 1990, 18, 56-59. [CrossRef] [PubMed]

23. Marichal, P.; Koymans, L.; Willemsens, S.; Bellens, D.; Verhasselt, P.; Luyten, W.; Borgers, M.; Ramaekers, F.C.S.; Odds, F.C.; Vanden Bossche, H. Contribution of mutations in the cytochrome P450 14alpha-demethylase (Erg11p, Cyp51p) to azole resistance in Candida albicans. Microbiology 1999, 145, 2701-2713. [CrossRef] [PubMed]

24. Lamb, D.C.; Corran, A.; Baldwin, B.C.; Kwon-Chung, J.; Kelly, S.L. Resistant P45051A1 activity in azole antifungal tolerant Cryptococcus neoformans from AIDS patients. FEBS Lett. 1995, 368, 326-330. [CrossRef]

25. Sanglard, D.; Ischer, F.; Koymans, L.; Bille, J. Amino acid substitutions in the cytochrome P-450 lanosterol 14alpha-demethylase (CYP51A1) from azole-resistant Candida albicans clinical isolates contribute to resistance to azole antifungal agents. Antimicrob. Agents Chemother. 1998, 42, 241-253. [CrossRef]

26. Park, S.; Kelly, R.; Kahn, J.N.; Robles, J.; Hsu, M.J.; Register, E.; Li, W.; Vyas, V.; Fan, H.; Abruzzo, G.; et al. Specific substitutions in the echinocandin target Fks1p account for reduced susceptibility of rare laboratory and clinical Candida sp. isolates. Antimicrob. Agents Chemother. 2005, 49, 3264-3273. [CrossRef]

27. Balashov, S.V.; Park, S.; Perlin, D.S. Assessing resistance to the echinocandin antifungal drug caspofungin in Candida albicans by profiling mutations in FKS1. Antimicrob. Agents Chemother. 2006, 50, 2058-2063. [CrossRef]

28. Vandeputte, P.; Ferrari, S.; Coste, A.T. Antifungal resistance and new strategies to control fungal infections. Int. J. Microbiol. 2012, 2012, 713687. [CrossRef]

29. Taff, H.T.; Mitchell, K.F.; Edward, J.A.; Andes, D.R. Mechanisms of Candida biofilm drug resistance. Future Microbiol. 2013, 8, 1325-1337. [CrossRef]

30. Mukherjee, P.K.; Chandra, J. Candida biofilm resistance. Drug Resist. Updates 2004, 7, 301-309. [CrossRef] 
31. Jabra-Rizk, M.A.; Falkler, W.A.; Meiller, T.F. Fungal biofilms and drug resistance. Emerg. Infect. Dis. 2004, 10, 14-19. [CrossRef]

32. Martinez, L.R.; Casadevall, A. Susceptibility of Cryptococcus neoformans biofilms to antifungal agents in vitro. Antimicrob. Agents Chemother. 2006, 50, 1021-1033. [CrossRef]

33. Hamal, P.; Ostransky, J.; Dendis, M.; Horváth, R.; Ruzicka, F.; Buchta, V.; Vejsova, M.; Sauer, P.; Hejnar, P.; Raclavsky, V. A case of endocarditis caused by the yeast Pichia fabianii with biofilm production and developed in vitro resistance to azoles in the course of antifungal treatment. Med. Mycol. 2008, 46, 601-605. [CrossRef]

34. Di Bonaventura, G.; Pompilio, A.; Picciani, C.; Iezzi, M.; D'Antonio, D.; Piccolomini, R. Biofilm formation by the emerging fungal pathogen Trichosporon asahii: Development, architecture, and antifungal resistance. Antimicrob. Agents Chemother. 2006, 50, 3269-3276. [CrossRef]

35. Seidler, M.J.; Salvenmoser, S.; Muller, F.M. Aspergillus fumigatus forms biofilms with reduced antifungal drug susceptibility on bronchial epithelial cells. Antimicrob. Agents Chemother. 2008, 52, 4130-4136. [CrossRef] [PubMed]

36. Rollin-Pinheiro, R.; de Meirelles, J.V.; Vila, T.V.M.; Fonseca, B.B.; Alves, V.; Frases, S.; Rozental, S.; Barreto-Bergter, E. Biofilm Formation by Pseudallescheria/Scedosporium Species: A Comparative Study. Front. Microbiol. 2017, 8, 1568. [CrossRef]

37. Veale, C.G.L. Unpacking the Pathogen Box-An Open Source Tool for Fighting Neglected Tropical Disease. ChemMedChem 2019, 14, 386-453. [CrossRef] [PubMed]

38. Vila, T.; Lopez-Ribot, J.L. Screening the Pathogen Box for Identification of Candida albicans Biofilm Inhibitors. Antimicrob. Agents Chemother. 2017, 61, 1-9. [CrossRef] [PubMed]

39. Mayer, F.L.; Kronstad, J.W. Discovery of a Novel Antifungal Agent in the Pathogen Box. mSphere 2017, 2, 1-12. [CrossRef] [PubMed]

40. Wall, G.; Herrera, N.; Lopez-Ribot, J.L. Repositionable Compounds with Antifungal Activity against Multidrug Resistant Candida auris Identified in the Medicines for Malaria Venture's Pathogen Box. J. Fungi 2019, 5, 92. [CrossRef]

41. Coelho, R.A.; Joffe, L.S.; Alves, G.M.; Figueiredo-Carvalho, M.H.G.; Brito-Santos, F.; Amaral, A.C.F.; Rodrigues, M.L.; AlmeidaPaes, R. A screening of the MMV Pathogen Box ${ }^{\circledR}$ reveals new potential antifungal drugs against the etiologic agents of chromoblastomycosis. PLoS ONE 2020, 15, e0229630. [CrossRef]

42. Borba-Santos, L.P.; Vila, T.; Rozental, S. Identification of two potential inhibitors of Sporothrix brasiliensis and Sporothrix schenckii in the Pathogen Box collection. PLoS ONE 2020, 15, e240658. [CrossRef]

43. Taj-Aldeen, S.J.; Salah, H.; Al-Hatmi, A.M.; Hamed, M.; Theelen, B.; van Diepeningen, A.D.; Boekhout, T.; Lass-Florl, C. In vitro resistance of clinical Fusarium species to amphotericin B and voriconazole using the EUCAST antifungal susceptibility method. Diagn. Microbiol. Infect. Dis. 2016, 85, 438-443. [CrossRef]

44. Rollin-Pinheiro, R.; Rochetti, V.P.; Xisto, M.; Liporagi-Lopes, L.C.; Bastos, B.; Rella, A.; Singh, A.; Rozental, S.; Del Poeta, M.; Barreto-Bergter, E. Sphingolipid biosynthetic pathway is crucial for growth, biofilm formation and membrane integrity of Scedosporium boydii. Future Med. Chem. 2019, 11, 2905-2917. [CrossRef]

45. Mello, T.P.; Aor, A.C.; Goncalves, D.S.; Seabra, S.H.; Branquinha, M.H.; Santos, A.L. Assessment of biofilm formation by Scedosporium apiospermum, S. aurantiacum, S. minutisporum and Lomentospora prolificans. Biofouling 2016, 32, 737-749. [CrossRef] [PubMed]

46. Mello, T.P.; Oliveira, S.S.C.; Frasés, S.; Branquinha, M.H.; Santos, A.L.S. Surface properties, adhesion and biofilm formation on different surfaces by Scedosporium spp. and Lomentospora prolificans. Biofouling 2018, 34, 800-814. [CrossRef] [PubMed]

47. Subcommittee on Antifungal Susceptibility Testing of the ESCMID European Committee for Antimicrobial Susceptibility Testing. EUCAST Technical Note on the method for the determination of broth dilution minimum inhibitory concentrations of antifungal agents for conidia-forming moulds. Clin. Microbiol. Infect. 2008, 14, 982-984. [CrossRef]

48. Rivero-Menendez, O.; Cuenca-Estrella, M.; Alastruey-Izquierdo, A. In vitro activity of olorofim against clinical isolates of Scedosporium species and Lomentospora prolificans using EUCAST and CLSI methodologies. J. Antimicrob. Chemother. 2020, 75, 3582-3585. [CrossRef]

49. Odds, F.C. Synergy, antagonism, and what the chequerboard puts between them. J. Antimicrob. Chemother. 2003, 52, 1. [CrossRef] [PubMed]

50. Zhao, W.; Sachsenmeier, K.; Zhang, L.; Sult, E.; Hollingsworth, R.E.; Yang, H. A New Bliss Independence Model to Analyze Drug Combination Data. J. Biomol. Screen. 2014, 19, 817-821. [CrossRef]

51. Meletiadis, J.; Petraitis, V.; Petraitiene, R.; Lin, P.; Stergiopoulou, T.; Kelaher, A.M.; Sein, T.; Schaufele, R.L.; Bacher, J.; Walsh, T.J. Triazole-polyene antagonism in experimental invasive pulmonary aspergillosis: In vitro and in vivo correlation. J. Infect. Dis. 2006, 194, 1008-1018. [CrossRef]

52. Harun, A.; Serena, C.; Gilgado, F.; Chen, S.C.; Meyer, W. Scedosporium aurantiacum is as virulent as S. prolificans, and shows strain-specific virulence differences, in a mouse model. Med. Mycol. 2010, 48 (Suppl. 1), S45-S51. [CrossRef]

53. Panackal, A.A.; Marr, K.A. Scedosporium/Pseudallescheria infections. Semin. Respir. Crit. Care Med. 2004, 25, 171-181. [CrossRef] [PubMed]

54. Mursch, K.; Trnovec, S.; Ratz, H.; Hammer, D.; Horré, R.; Klinghammer, A.; de Hoog, S.; Behnke-Mursch, J. Successful treatment of multiple Pseudallescheria boydii brain abscesses and ventriculitis/ependymitis in a 2-year-old child after a near-drowning episode. Childs Nerv. Syst. 2006, 22, 189-192. [CrossRef] 
55. Tammer, I.; Tintelnot, K.; Braun-Dullaeus, R.C.; Mawrin, C.; Scherlach, C.; Schluter, D.; Konig, W. Infections due to Pseudallescheria/Scedosporium species in patients with advanced HIV disease-a diagnostic and therapeutic challenge. Int. J. Infect. Dis. 2011, 15, e422-e429. [CrossRef]

56. Schwarz, C.; Brandt, C.; Antweiler, E.; Krannich, A.; Staab, D.; Schmitt-Grohe, S.; Fischer, R.; Hartl, D.; Thronicke, A.; Tintelnot, K. Prospective multicenter German study on pulmonary colonization with Scedosporium /Lomentospora species in cystic fibrosis: Epidemiology and new association factors. PLoS ONE 2017, 12, e0171485. [CrossRef] [PubMed]

57. Heath, C.H.; Slavin, M.A.; Sorrell, T.C.; Handke, R.; Harun, A.; Phillips, M.; Nguyen, Q.; Delhaes, L.; Ellis, D.; Meyer, W.; et al. Population-based surveillance for scedosporiosis in Australia: Epidemiology, disease manifestations and emergence of Scedosporium aurantiacum infection. Clin. Microbiol. Infect. 2009, 15, 689-693. [CrossRef] [PubMed]

58. Dos Reis, T.F.; Horta, M.A.C.; Colabardini, A.C.; Fernandes, C.M.; Silva, L.P.; Bastos, R.W.; Fonseca, M.V.L.; Wang, F.; Martins, C.; Rodrigues, M.L.; et al. Screening of Chemical Libraries for New Antifungal Drugs against Aspergillus fumigatus Reveals Sphingolipids Are Involved in the Mechanism of Action of Miltefosine. mBio 2021, 12, e01458-21. [CrossRef] [PubMed]

59. Fuchs, B.B.; RajaMuthiah, R.; Souza, A.C.; Eatemadpour, S.; Rossoni, R.D.; Santos, D.A.; Junqueira, J.C.; Rice, L.B.; Mylonakis, E. Inhibition of bacterial and fungal pathogens by the orphaned drug auranofin. Future Med. Chem. 2016, 8, 117-132. [CrossRef] [PubMed]

60. Wiederhold, N.P.; Patterson, T.F.; Srinivasan, A.; Chaturvedi, A.K.; Fothergill, A.W.; Wormley, F.L.; Ramasubramanian, A.K.; Lopez-Ribot, J.L. Repurposing auranofin as an antifungal: In vitro activity against a variety of medically important fungi. Virulence 2017, 8, 138-142. [CrossRef]

61. Yaakoub, H.; Staerck, C.; Mina, S.; Godon, C.; Fleury, M.; Bouchara, J.P.; Calenda, A. Repurposing of auranofin and honokiol as antifungals against Scedosporium species and the related fungus Lomentospora prolificans. Virulence 2021, 12, 1076-1090. [CrossRef]

62. Siles, S.A.; Srinivasan, A.; Pierce, C.G.; Lopez-Ribot, J.L.; Ramasubramanian, A.K. High-throughput screening of a collection of known pharmacologically active small compounds for identification of Candida albicans biofilm inhibitors. Antimicrob. Agents Chemother. 2013, 57, 3681-3687. [CrossRef]

63. Thangamani, S.; Maland, M.; Mohammad, H.; Pascuzzi, P.E.; Avramova, L.; Koehler, C.M.; Hazbun, T.R.; Seleem, M.N. Repurposing Approach Identifies Auranofin with Broad Spectrum Antifungal Activity That Targets Mia40-Erv1 Pathway. Front. Cell. Infect. Microbiol. 2017, 7, 4. [CrossRef]

64. May, H.C.; Yu, J.J.; Guentzel, M.N.; Chambers, J.P.; Cap, A.P.; Arulanandam, B.P. Repurposing Auranofin, Ebselen, and PX-12 as Antimicrobial Agents Targeting the Thioredoxin System. Front. Microbiol. 2018, 9, 336. [CrossRef] [PubMed]

65. Abutaleb, N.S.; Seleem, M.N. Repurposing the Antiamoebic Drug Diiodohydroxyquinoline for Treatment of Clostridioides difficile Infections. Antimicrob. Agents Chemother. 2020, 64, 1-11. [CrossRef] [PubMed]

66. Liu, Q.; Yin, X.; Languino, L.R.; Altieri, D.C. Evaluation of drug combination effect using a Bliss independence dose-response surface model. Stat. Biopharm. Res. 2018, 10, 112-122. [CrossRef]

67. Demidenko, E.; Miller, T.W. Statistical determination of synergy based on Bliss definition of drugs independence. PLoS ONE 2019, 14, e224137. [CrossRef] [PubMed]

68. Harbut, M.B.; Vilchèze, C.; Luo, X.; Hensler, M.E.; Guo, H.; Yang, B.; Chatterjee, A.K.; Nizet, V.; Jacobs, W.R., Jr.; Schultz, P.G.; et al. Auranofin exerts broad-spectrum bactericidal activities by targeting thiol-redox homeostasis. Proc. Natl. Acad. Sci. USA 2015, 112, 4453-4458. [CrossRef]

69. Owings, J.P.; McNair, N.N.; Mui, Y.F.; Gustafsson, T.N.; Holmgren, A.; Contel, M.; Goldberg, J.B.; Mead, J.R. Auranofin and N-heterocyclic carbene gold-analogs are potent inhibitors of the bacteria Helicobacter pylori. FEMS Microbiol. Lett. 2016, 363, 1-6. [CrossRef]

70. Gandin, V.; Fernandes, A.P.; Rigobello, M.P.; Dani, B.; Sorrentino, F.; Tisato, F.; Björnstedt, M.; Bindoli, A.; Sturaro, A.; Rella, R.; et al. Cancer cell death induced by phosphine gold (I) compounds targeting thioredoxin reductase. Biochem. Pharmacol. 2010, 79, 90-101. [CrossRef]

71. Feng, L.; Pomel, S.; Latre de Late, P.; Taravaud, A.; Loiseau, P.M.; Maes, L.; Cho-Ngwa, F.; Bulman, C.A.; Fischer, C.; Sakanari, J.A.; et al. Repurposing Auranofin and Evaluation of a New Gold (I) Compound for the Search of Treatment of Human and Cattle Parasitic Diseases: From Protozoa to Helminth Infections. Molecules 2020, 25, 5075. [CrossRef] [PubMed]

72. Thangamani, S.; Mohammad, H.; Abushahba, M.F.; Sobreira, T.J.; Seleem, M.N. Repurposing auranofin for the treatment of cutaneous staphylococcal infections. Int. J. Antimicrob. Agents 2016, 47, 195-201. [CrossRef] [PubMed]

73. Kean, W.F.; Hart, L.; Buchanan, W.W. Auranofin. Br. J. Rheumatol. 1997, 36, 560-572. [CrossRef] [PubMed]

74. Roder, C.; Thomson, M.J. Auranofin: Repurposing an old drug for a golden new age. Drugs RD 2015, 15, 13-20. [CrossRef]

75. Lawung, R.; Cherdtrakulkiat, R.; Nabu, S.; Prachayasittikul, S.; Isarankura-Na-Ayudhya, C.; Prachayasittikul, V. Repositioning of 8-hydroxyquinoline derivatives as a new promising candidate for combating multidrug resistant Neisseria gonorrhoeae. EXCLI J. 2018, 17, 840-846. [CrossRef] [PubMed]

76. Martínez-Castillo, M.; Pacheco-Yepez, J.; Flores-Huerta, N.; Guzmán-Téllez, P.; Jarillo-Luna, R.A.; Cárdenas-Jaramillo, L.M.; Campos-Rodríguez, R.; Shibayama, M. Flavonoids as a Natural Treatment Against Entamoeba histolytica. Front. Cell. Infect. Microbiol. 2018, 8, 209. [CrossRef] [PubMed] 